\title{
CONTRACTELE CLICKWRAP - TERENUL \\ PROPICE AL CLAUZELOR ABUZIVE. O \\ ANALIZĂ DE CAZ
}

\section{Christian-Dorel GROSU*}

Rezumat: Cu ocazia creării câte unui nou cont de e-mail, a cumpărării unui bun prin intermediul unor platforme precum eMag sau elefant.ro o persoană încheie contracte ale căror clauze sunt de multe ori abuzive; clauze în fața cărora orice consumator pare a fi lipsit de mecanisme juridice de apărare. Cele mai des întâlnite astfel de clauze sunt cele de alegere a legii aplicabile contractului și cele de alegere a forului în cazul ivirii unor litigii. Consumatorului îi vin în ajutor atât legislația națională (Legea 193/2000), cât și cea europeană, precum și jurisprudența Curții de Justiție a Uniunii Europene în materie.

Cuvinte-cheie: clauze abuzive, consumator, Legea 193/2000

* Christian-Dorel Grosu, masterand in cadrul specializarii „Dreptul european si dreptul national al afacerilor". Facultatea de Drept a Universității Babeș-Bolyai, contact: christiandorel.grosu@law.ubbcluj.ro. 


\title{
CLICKWRAP CONTRACTS - THE SUITABLE TERRAIN FOR ABUSIVE CLAUSES. A CASE STUDY
}

\begin{abstract}
On the occasion of creating a new email account, of buying a good through the use of platforms such as eMag or elefant.ro, a person signs contracts whose clauses are many times abusive; clauses which, if faced with, seem to render the consumer stripped of legal means of protection. The most widely encountered clauses such as the above are the choice-of-law clauses and the forum selection clauses. Rushing to the consumer's aid is the national legislation (Law no. 193/2000), as well as the European one and the case law of the Court of Justice of the European Union.
\end{abstract}

Key-words: abusive clauses, consumer, Law 193/2000

Contractele electronice reprezintă un instrument folosit de către dezvoltatorii lumilor virtuale, dezvoltatorii feluritelor platforme informatice, societăți etc., cuprinzând clauze ce îl favorizează în mod substanțial pe profesionistul în cauză. Ele se perfectează online și, de regulă, se întâlnesc sub forma contractelor de tip click-wrap ${ }^{1}$, guvernând raportul juridic dintre cel ce acordă licența ${ }^{2}$ în cauză și cel ce o acceptă. ${ }^{3}$ Contractele de tip click-wrap se încheie prin bifarea unei casete corespunzătoare răspunsului „Da”, „Accept”,

${ }^{1}$ C. T. Ungureanu, Contractul electronic, Revista „Dreptul”, nr. 9, 2015, p. 165.

${ }^{2}$ Prin intermediul contractelor E.U.L.A. (End User License Agreement) și T.O.S. (Terms of Service) utilizatorului i se acordă o licență (un drept) restrâns de a folosi o platformă, datele informatice etc., puse la dispoziție de către dezvoltator, care își rezervă dreptul exclusiv de proprietate asupra a tot ceea ce a creat și are legătură cu creația sa. Utilizarea platformei necesită acordul prealabil al utilizatorului cu privire la cele două contracte, în lipsa exprimării consimțământului acesta neavând acces la platformă; situația este similară cu cea a contractelor de adeziune.

${ }^{3}$ J. S. CHAo, Recognizing Virtual Property Rights, It's About Time, Law School Student Scholarship, 2010, p. 4. 
ceea ce implică, din punctul nostru de vedere, manifestarea expresă a consimțământului de a adera la formula contractuală. ${ }^{4}$ Este forma specifică pe care clauzele standard o îmbracă în mediul online. ${ }^{5}$

În mod ubicuu, indiferent de profesionistul a cărui formulă contractuală este analizată, în contractele electronice se stipulează expres că tot ceea ce ține, spre exemplu, de lumile virtuale este proprietatea intelectuală a dezvoltatorului. Dezvoltatorii lumilor virtuale nu se limitează la dreptul de proprietate pe care îl exercită asupra creației virtuale a căror autori sunt; uneori, aceștia vând utilizatorilor felurite bunuri virtuale, însă nici în această situație dreptul de proprietate al utilizatorilor nu este recunoscut. ${ }^{6}$

În continuare, va fi luat drept exemplu, în cadrul unui succint studiu de caz, contractul E.U.L.A. 7 folosit de către compania Blizzard Entertainment Inc., însoțit de verificarea măsurii în care acesta poate forma obiectul aplicării teoriei clauzelor abuzive și al dispozițiilor legale în materie. Din această perspectivă, urmează să procedăm la examinarea unor prevederi referitoare, cu precădere, la soluționarea litigiilor pe cale arbitrală şi legea aplicabilă contractului.

În cadrul contractului se fac trimiteri la dispoziții cuprinse în pagini web distincte; una dintre aceste dispoziții prevede că utilizatorilor le este

${ }^{4}$ J. M. Moringiello, W. L. ReYnolds, Electronic Contracting Cases 2009-2010, Business Lawyer, Vol. 66, 2010, p. 2.

${ }^{5}$ M. A. LEMLey, Terms of Use, Minnesota Law Review, no. 459, 2006, pp. 465-466.

6 Pentru detalii, a se vedea https://www.blizzard.com/en-us/legal/fba4d00f-c7e4-4883-b8b91b4500a402ea/blizzard-end-user-license-agreement, consultat la 27.08.2020, ora 15:02.

7 E.U.L.A. constituie acronimul corespunzător denumirii din limba engleză a contractului prin care profesionistul acordă utilizatorului o licență (un drept) restrâns de a folosi cele puse la dispoziție de către acesta dintâi (spre exemplu, o platformă, anumite date informatice etc.), contract denumit „End User License Agreement”. 
îngăduită încărcarea de conținut în cadrul lumii virtuale, precum și pe forumul companiei, însă în ipoteza în care acest material are caracter original, cu potențial creativ, se consideră că utilizatorul a acordat Blizzard un drept perpetuu, irevocabil, general, non-exclusiv de a se bucura de emolumentul rezultat, sens în care Blizzard are dreptul de a efectua copii, reproduce, modifica, adapta, reformata, publica, distribui, vinde etc., respectivul conținut. Această clauză este injustă pentru autorul conținutului, deși poziția acestuia este comparabilă cu cea a unei persoane ce a creat conținut prin intermediul instrumentelor puse la dispoziție de aplicațiile Word. Cum ar fi ca în acest din urmă exemplu dezvoltatorii Word să decidă ca orice conținut creat în Word să constituie obiect al dreptului lor de proprietate? ${ }^{8}$ Această comparație reliefează caracterul abuziv al clauzei de mai sus.

Acelaşi contract prevede și legea aplicabilă acestuia, cea a Statelor Unite ale Americii; utilizatorii care accesează platforma din afara Statelor Unite ale Americii și Canadei se supun prevederilor menționate.

Contractul E.U.L.A. trimite încă odată la dispoziții prevăzute într-o pagină web distinctă, unde sunt stipulate regulile privitoare la eventuale litigii甲9. Potrivit acestor reguli, litigiile urmează să fie soluționate pe calea arbitrajului, pentru persoanele domiciliate în afara Statelor Unite ale Americii fiind competentă, potrivit clauzelor contractuale, autoritatea de arbitraj din Los Angeles, California.

Abuzul de drept pe tărâm contractual poate îmbrăca, potrivit doctrinei de factură common law, două forme: un abuz procedural și unul substanțial.

\footnotetext{
${ }^{8}$ J. S. CHAO, op.cit., pp. 14-15.

${ }^{9}$ Pentru detalii, a se vedea https://www.blizzard.com/en-us/legal/b2eobo82-fddb-4824-93faee9c1bf814f8/blizzard-entertainment-dispute-resolution-policy, consultat la 27.02.2020, ora $16: 22$.
} 
Abuzul procedural presupune lipsa oricărui mijloc de negociere de către una dintre părți (de regulă, cea dezavantajată), în vreme ce abuzul substanțial privește existența unor clauze stabilite în mod exclusiv în beneficiul unei părți (de regulă, cea aflată pe o poziție de superioritate). ${ }^{10}$

Doctrina noastră de drept civil ${ }^{11}$ face distincţie între contractele negociate şi cele de adeziune, după cum ele au fost supuse negocierii sau nu. Potrivit art. 1175 C.civ. „contractul este de adeziune atunci când clauzele sale esențiale sunt impuse ori sunt redactate de către una dintre părți, pentru aceasta sau ca urmare a instrucțiunilor sale, cealaltă parte neavând decât să le accepte ca atare”. Conținutul acestor clauze este prestabilit în totalitate de către una dintre părți, fără ca celeilalte părți să i se ofere posibilitatea de a le influenţa. ${ }^{12}$ Clauzele acestea se numesc clauze standard și sunt reglementate de legislatorul român în art. 1202 C.civ. care, la alin. (2), prevede că „sunt clauze standard stipulațiile stabilite în prealabil de una dintre părți pentru a fi utilizate în mod general și repetat și care sunt incluse în contract fără să fi fost negociate cu cealaltă parte”.

Potrivit doctrinei ${ }^{13}$, trăsăturile specifice ale contractului de adeziune sunt inegalitatea economică ori profesională a părților, caracterul general și standardizat al ofertei și absența oricărei negocieri.

La art. 1203 C.civ. se reglementează clauzele neuzuale în următoarea manieră: „clauzele standard care prevăd în folosul celui care le propune

\footnotetext{
${ }^{10}$ E. Reuveni, On Virtual Worlds: Copyright and Contract Law at the Dawn of the Virtual Age, Indiana Law Journal, Vol. 82, No. 261, 2007, p. 300.

${ }^{11}$ L. POP, I.-F. POPA, S. Ioan VIDU, Curs de drept civil. Obligațiile, Universul Juridic, București, 2015, pp. 46-48.

${ }^{12}$ Ibidem.

13 Ibidem.
} 
limitarea răspunderii, dreptul de a denunța unilateral contractul, de a suspenda executarea obligațiilor sau care prevăd în detrimentul celeilalte părți decăderea din drepturi ori din beneficiul termenului, limitarea dreptului de a opune excepții, restrângerea libertății de a contracta cu alte persoane, reînnoirea tacită a contractului, legea aplicabilă, clauze compromisorii sau prin care se derogă de la normele privitoare la competența instanțelor judecătorești nu produc efecte decât dacă sunt acceptate, în mod expres, în scris, de cealaltă parte”. Această enumerare nu este una cu caracter limitativ, iar includerea unei clauze între cele de mai sus are drept consecință prezumarea stipulațiilor ca lipsite de transparență, pe această cale fiind simplificată probarea caracterului lor abuziv.

Protecţia părții mai slabe din punct de vedere economic a constituit o preocupare a legislatorului, atât autohton, cât și unional. În acest sens, a fost adoptată Legea nr. 193/2000 privind clauzele abuzive din contractele încheiate între profesioniști şi consumatori ${ }^{14}$. Actul normativ în cauză transpune prevederile Directivei Consiliului 93/13/CEE din $1993^{15}$.

La prima vedere, raportat la contractul E.U.L.A. folosit de către Blizzard, actul normativ unional și cel de drept intern nu prezintă importanță, întrucât se stabilește clar că legea aplicabilă este cea a Statelor Unite ale Americii, ale cărei prevederi sunt întru totul aplicabile. Cu toate acestea, lecturarea părții de început a contractului oferă un detaliu important: în măsura în care persoana în cauză nu îşi are domiciliul, reședința/nu locuiește

\footnotetext{
${ }^{14}$ Legea nr. 193/200o privind clauzele abuzive din contractele încheiate între profesioniști și consumatori, M.of.: 543 din 3 august 2012.

${ }^{15}$ Directiva 93/13/CEE a Consiliului din 5 aprilie 1993 privind clauzele abuzive în contractele încheiate cu consumatorii, publicată în Jurnalul Oficial al Uniunii Europene L 95, ediție specială, 15/vol. 002, pp. 273-278.
}

\section{7}


în Statele Unite ale Americii, Canada sau Mexic, licența se acordă de către Activision Blizzard International B.V. ${ }^{16}$, cu sediul în Amstelveen, Olanda. Art. 15 al Legii nr. 193/2000 prevede că „în cazul în care părțile contractante aleg ca lege aplicabilă contractului legea unui stat care nu face parte din Uniunea Europeană, iar contractul are o strânsă legătură cu teritoriul României sau cu al altor state membre ale Uniunii Europene și în cazul în care prezenta lege are prevederi mai favorabile pentru consumator, se vor aplica acestea din urmă" (art. 6 alin. (2) din directivă). ${ }^{17}$

În speță, părţile au ales ca lege aplicabilă legea Statelor Unite ale Americii, dar se poate argumenta că respectivul contract are o legătură mai strânsă, în fapt și în drept, cu spațiul unional. Se precizează în Legea nr. 193/2000 că legătura mai strânsă trebuie să fie cu teritoriul României sau al altor state membre, sugerând un caracter alternativ între cele două; în această ordine de idei, ar trebui verificate elementele componente ale contractului pentru a se identifica teritoriul în relație cu care acestea au o legătură mai strânsă și mai caracterizată. În ciuda caracterului aparent alternativ al criteriilor teritoriale trebuie avut în vedere faptul că, deși transpusă pe calea unui act intern cu putere de lege, directiva continuă să aibă valoare interpretativă, prevederile legii naționale adoptate pentru punerea în aplicare a directivei trebuind să fie interpretate în concordanță cu actul unional. Pe această cale,

\footnotetext{
16 B. V. este abrevierea pentru „besloten vennootschap”, adică ”societate cu răspundere limitată", în limba olandeză.

${ }^{17}$ Potrivit preambulului directivei, această dispoziție a fost concepută pentru a evita situațiile în care consumatorul este privat de protecția necesară prin alegerea ca aplicabilă a unei legi aparținând unui stat nemembru.
} 
art. 6 alin. (2) din directivă prevede: „Statele membre iau măsurile necesare pentru a se asigura că consumatorul nu își pierde protecția acordată prin această directivă datorită alegerii legislației unui stat nemembru ca legislație aplicabilă contractului, în cazul în care acesta din urmă are o strânsă legătură cu teritoriul statelor membre”. Directiva face referire la teritoriul statelor membre, global, prin urmare la ansamblul teritoriului statelor care fac parte din Uniunea Europeană, ceea ce permite ca elementele componente ale contractului să fie luate în considerare laolaltă, chiar dacă unele dintre acestea sugerează o legătură cu un anumit stat membru, iar altele o legătură cu un alt stat membru. Din acest punct de vedere, există cel puțin patru elemente care indică o legătură suficient de caracterizată cu teritoriul unional: domiciliul utilizatorului este situat în cadrul spațiului unional, sediul societăţii Activision Blizzard International B.V., locul unde se fac plățile de către utilizator, situarea serverelor lumii virtuale.

Potrivit contractului E.U.L.A., acesta se încheie între utilizator și Activision Blizzard International B.V., cu sediul în Olanda, în măsura în care utilizatorul nu are domiciliul/reședința/nu locuiește în Statele Unite ale Americii, Canada sau Mexic. Societatea în cauză este o societate cu răspundere limitată, prin urmare are personalitate juridică proprie, distinctă de cea a Blizzard Entertainment Inc.; pe deasupra, contractul prevede: „Blizzard Entertainment, Inc., and Activision Blizzard International B.V. are referred to herein as [...]”. Se poate deduce din modalitatea de formulare că cele două entități sunt separate, cu atât mai mult cu cât ambele au personalitate juridică de sine stătătoare ${ }^{18}$.

\footnotetext{
18 În caz contrar, ar fi fost mai anevoioasă demonstrarea legăturii contractului cu spațiul unional, întrucât o serie de elemente de legătură nu ar mai fi putut fi luate în calcul, spre exemplu sediul societăţii.
} 
Legea nr. 193/2000 prevede la art. 1 alin. (3) că „se interzice profesioniștilor stipularea de clauze abuzive în contractele încheiate cu consumatorii”, iar alin. (1) al art. 4 statuează că „o clauză contractuală care nu a fost negociată direct cu consumatorul va fi considerată abuzivă dacă, prin ea însăşi sau împreună cu alte prevederi din contract, creează, în detrimentul consumatorului şi contrar cerințelor bunei-credințe, un dezechilibru semnificativ între drepturile și obligațiile părților.” Această dispoziție se coroborează cu cea de la alin. (2), potrivit căruia „o clauză contractuală va fi considerată ca nefiind negociată direct cu consumatorul dacă aceasta a fost stabilită fără a da posibilitate consumatorului să influențeze natura ei, cum ar fi contractele standard preformulate sau condițiile generale de vânzare practicate de profesioniști pe piața produsului sau serviciului respectiv".

Din cuprinsul art. 4 alin. (1) al Legii nr. 193/200o rezultă elementele de identificare ale clauzelor abuzive.

În primul rând, acestea nu sunt negociate. Ele sunt asociate contractelor de adeziune, redactate unilateral de către partea ce propune contractul, fără a permite negocierea prevederilor sale, indiferent dacă permite sau nu înțelegerea acestora. Prin asemenea contracte, profesionistului i se conferă o poziție dominantă, iar consumatorul nu poate decât să adere la contract, în formula în care acesta este propus de către profesionist.

În al doilea rând, contractul trebuie să creeze o situație de dezechilibru între cele două părți. Potrivit Legii nr. 193/2000, acest dezechilibru este unul juridic, între drepturile și obligațiile părților, în detrimentul consumatorului. Acest dezechilibru este vădit în situația analizată aici, cel puțin din perspectiva faptului că se prevede cu titlu de regulă generală, în favoarea Activision Blizzard International B.V., soluționarea litigiilor pe cale arbitrală de către o 
autoritate competentă din Statele Unite ale Americii; pe calea acestei clauze compromisorii, datorită costurilor extrem de ridicate pe care soluționarea pe cale arbitrală a litigiului le-ar prezenta pentru consumatori, aceștia din urmă se află în situația unei lipse de acces la justiție. ${ }^{19}$ De asemenea, potrivit anexei la Legea nr. 193/2000, sunt abuzive clauzele care „exclud dreptul consumatorului [...] de a exercita un alt remediu legal, solicitându-i în același timp rezolvarea disputelor în special prin arbitraj”. Această viziune a fost împărtășită, de altfel, și de alți autori. ${ }^{20}$

În al treilea rând, pentru a se stabili fără putință de tăgadă că o clauză contractuală este abuzivă este necesară încălcarea exigenței de bună-credință. Rolul acestei condiții este acela de a „preîntâmpina o posibilă evaluare mecanică a dezechilibrului între drepturile și obligațiile părților, precum și de a impune ca la evaluarea caracterului abuziv al unei clauze să se aibă în vedere toate circumstanțele relevante ale încheierii contractului" ${ }^{21}$.

În al patrulea rând, potrivit art. 4 alin. (4) din Legea nr. 193/2000, „lista cuprinsă în anexa care face parte integrantă din prezenta lege redă, cu titlu de exemplu, clauzele considerate ca fiind abuzive". După cum se specifică și în actul normativ, lista nu este una cu caracter exhaustiv. Prin hotărârea pronunțată în cauza C-478/99 (Comisia c. Regatului Suediei) s-a stabilit că lista cuprinsă în anexa directivei are caracter orientativ, astfel că încadrarea unei clauze între cele enumerate în anexă nu duce automat la declararea acesteia ca fiind abuzivă. ${ }^{22}$ Pentru a fi considerate potențial abuzive, aceste

\footnotetext{
${ }^{19}$ L. Pop, I.-F. PoPA, S. Ioan Vidu, passim.

${ }^{20}$ Pentru detalii a se vedea C. T. Ungureanu, op.cit., pp. 179-180.

${ }^{21}$ L. Pop, I.-F. PopA, S. Ioan VIDU, passim.

${ }^{22}$ Curtea de Justiție a Uniunii Europene, Cauza C-478/99, Comisia c. Regatului Suediei, ECLI:EU:C:2002:281.
} 
clauze trebuie, pe lângă a se regăsi în enumerarea cuprinsă în lege, să fie stabilite în favoarea profesionistului. ${ }^{23}$

Atât în jurisprudența Curții de Justiție a Uniunii Europene, cât și în doctrina noastră, s-a stabilit că sancțiunea adecvată este cea a nulității absolute a acestor clauze ${ }^{24}$. Potrivit art. 7 din Legea nr. 193/2000, ,în măsura în care contractul nu își mai poate produce efectele după înlăturarea clauzelor considerate abuzive, consumatorul este îndreptățit să ceară rezilierea contractului, putând solicita, după caz, și daune-interese”. Din interpretarea acestui articol se poate deduce faptul că nulitatea este una parțială, urmând ca efectele sale să se extindă asupra contractului în integralitate numai cu titlu excepțional, în situația în care aneantizarea clauzelor abuzive duce la imposibilitatea continuării executării sale.

În concluzie, întrucât majoritatea contractelor de tip click-wrap implică acceptarea unor termeni și condiții ce stau la baza dezechilibrului juridic dintre părțile contractante, acestea pot constitui obiect al aplicării teoriei clauzelor abuzive. ${ }^{25}$ În special clauzele compromisorii ce stabilesc competența de soluționare a litigiilor în sarcina unor autorități de arbitraj străine sistemului de drept continental și unional și clauzele de electiojuris ce trimit la sisteme de drept precum cel din cazul analizat pot constitui obiect al teoriei clauzelor abuzive, cu consecința anulării lor, fără ca acestea să fie singurele situații în cazul cărora teoria antemenționată își găsește aplicabilitatea. În ipoteza anulării acestor clauze urmează a se aplica

\footnotetext{
${ }^{23}$ L. PoP, I.-F. PopA, S. Ioan VIDU, op.cit., p. 97.

${ }^{24}$ Curtea de Justiție a Uniunii Europene, Cauza C-240/98-C 244/98, Océano Grupo Editorial SA c. Rocio Murciano Quintero, ECLI:EU:C:2000:346.

25 T. J. CALlOWAY, Cloud computing, click-wrap agreements, and limitation on liability clauses: a perfect storm?, Duke Law and Technology Review, vol. 11, no. 1, 2012, pp. 170-172.
} 
reglementările specifice de drept internațional privat, de altfel preferabile inclusiv profesioniștilor în locul susținerii unui proces în materia dreptului consumului. 